\title{
Evaluating Environmental and Social Performance of Large Portuguese Companies: A Balanced Scorecard Approach
}

\author{
Idalina Dias-Sardinha'* and Lucas Reijnders ${ }^{2}$ \\ 'IVAM, University of Amsterdam, The Netherlands, and FCT, \\ New University of Lisbon, Portugal \\ ${ }^{2}$ IBED, University of Amsterdam, The Netherlands
}

\begin{abstract}
A thematic balanced scorecard format was used to address environmental and social performance evaluation of 13 large companies operating in Portugal. Financial aspects of environmental and social company activities are also included. Companies were categorized as to their actual performance status using a predefined performance framework. Three categories were found: compliance with the law while emphasizing pollution control, pollution prevention and eco-efficiency. Management tools and procedural matters were found to be most relevant for categorization. Often, reported information did not allow for quantitative evaluation of environmental burden reduction.

Use of the thematic balanced scorecard format was useful to better understand the strengths and weaknesses of links between objectives and measurements, initiatives and achievements. Improvement as to environmental performance was found to be paralleled by increased social performance, suggesting that a multi-level 'sustainability' performance categorization of these Portuguese companies is feasible. Driving forces for environmental management initiatives were found to differ by category of performance. Copyright (C) 2005 John Wiley \& Sons, Ltd and ERP Environment.
\end{abstract}

Received 26 February 2003; revised 10 September 2003; accepted 6 November 2003

Keywords: balanced scorecard; environmental performance; social performance; eco-efficiency; Portugal

* Correspondence to: Idalina Dias-Sardinha, University of Amsterdam, IVAM, Roetersstraat 33, PO Box 18180, 1001 ZB Amsterdam, The Netherlands. E-mail: limadias@sapo.pt 


\section{Introduction}

NVIRONMENTAL PERFORMANCE EVALUATION IS, ACCORDING TO THE INTERNATIONAL STANDARDS Organization (ISO) I403I (I999), a 'process to facilitate management decisions regarding an organization's environmental performance by selecting indicators, collecting and analysing data, assessing information against environmental performance criteria, reporting and communicating and periodically reviewing and improving this process'.

Many environmental performance evaluation models for organizations have been proposed (see, e.g., Azzone and Manzini, I994; Bartolomeo, I995; Wehrmeyer, I995; Callens and Tyteca, I995; Azzone et al., I996; BMU and UBA, I997; Eagan and Joeres, I997; Skillius and Wennberg, I998; Bennett and James, I999; ISO I403I, I999; Lehni, I999; Thoresen, I999; Young and Welford, I999; Mauser, 200I; Olsthoorn et al., 200I).

With the emerging interest in corporate social responsibility, models for sustainability performance evaluation have also been proposed for self-assessment, benchmarking and reporting (see, e.g., DJSGI, I999; Atkinson, 2000; BSI et al., 200I; Veleva and Ellenbecker, 200I; GRI, 2002; Azapagic, 2004). These models cover environmental, social and economic aspects of company performance.

The operationalization of environmental and sustainability performance evaluation in companies needs guidance regarding the choice of adequate objectives, targets to achieve and indicators (Bennett and James, I999; Upham, 2000). Besides, evaluation formats need to be designed on the basis of the company's current and intended future performance level.

A variety of companies' environmental management classifications have been proposed to deal with the development over time of companies' environmental responses and environmental performance (see, e.g., Hunt and Auster, I990; Roome, I992; Callens and Wolters, I998; Ghobadian et al., I998). Those models deal with different perspectives on or dimensions of company environmental performance. Companies are classified in terms of stages or types dependent on criteria that are related to these perspectives e.g., internal processes and business environment. These models have been criticized as to the subjectivity of classification, their mostly (linear) evolutionary character and the difficulty of putting them into practice (Hass, I996; van Hemel, I998; Kolk, 2000; Mauser, 200I). On the other hand, environmental management classification models have also been argued to be useful (AragonCorrea, I998; de Bakker, 200I; Bieker and Gminder, 200I). Kolk (2000) has in this context stressed the importance of specifying management characteristics and performance indicators.

To deal with the need for guidance regarding performance references (also called performance criteria or performance destination points), we defined an essentially evolutionary performance framework (Dias-Sardinha and Reijnders, 200I) (see Figure I). This framework links environmental and 'sustainability' strategic objectives, performance references and performance evaluation format, while specifying management characteristics and performance indicators.

The performance framework includes six broad strategic objectives: compliance with the law while emphasizing pollution control, pollution prevention, eco-efficiency, eco-innovation, eco-ethics and sustainability. The first three strategic objectives and associated performance references are summarized in Table I, as they are particularly relevant to the present study.

Strategic objectives such as given in Table I may be found in companies as result of strategic planning or due to the introduction of emergent concepts (Kolk, 2000). They reflect major differences in expected environmental and, where applicable, social performance. Though the framework is essentially evolutionary no claim was made as to linear progress along the categories or to precise borders between categories.

For each strategic objective core performance references were indicated, referring mainly to the internal dimension as procedural matters, use of management tools and technology and reduction of 


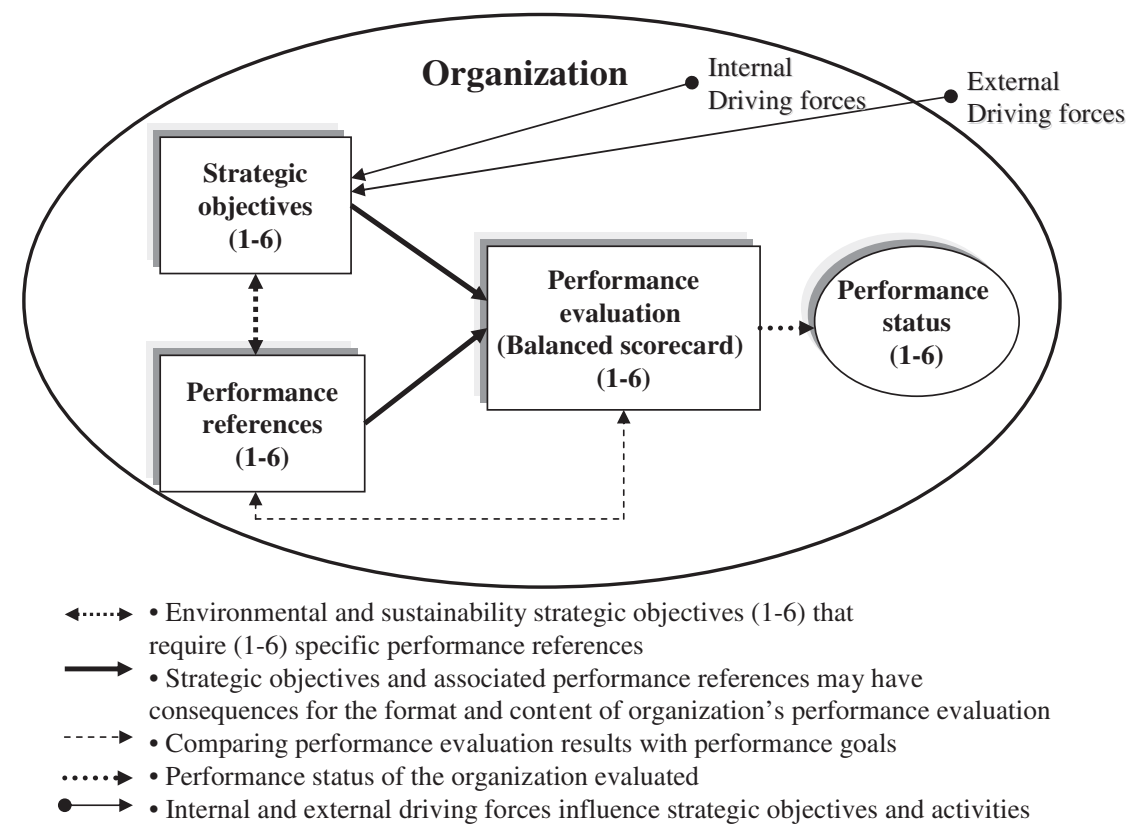

Figure 1. Performance framework

Strategic objectives

Performance references

\section{Compliance}

Compliance with relevant regulations, voluntary agreements (such as covenants) and general codes of conduct voluntarily adhered to, emphasizing pollution control

\section{Pollution prevention}

Optimization of resource consumption and prevention of waste (including emissions) with emphasis on production and highly negative-impact wastes, in line with financial targets of the company, such as cost reduction

\section{Eco-efficiency}

Reduction of resource intensity and minimization of environmental impacts of production and products/services, together with value creation by continuous incremental improvement
- No violations of regulations, voluntary agreements and general codes of conduct voluntarily adhered to. Violations include both substantive and procedural environmental matters: such as having an adequate monitoring and/or environmental management system

- Reference values of best preventive technologies and practices available to the sector

- Proactive attitude concerning future changes in the law

- Reduction of environmental burden with up to a factor of 1.5 (FX $\leq 30 \%$ reduction) (van Berkel, 2000) if compared with average company in compliance

- Procedural: effective management structure for pollution prevention, preferably following standards related to an environmental management system, with effective monitoring and information systems

- Application of most eco-efficient practices, technologies and products/services available, preferably using a product life-cycle perspective

- Reduction of environmental burden up to a factor of 4 (30\% $\leq \mathrm{FX} \leq 75 \%$ reduction) if compared with average company in compliance

- Value creation coupled with continuous improvement

- Procedural: following standards related to an environmental management system

Table 1. Strategic objectives and related performance references for organizations

Adapted from Dias-Sardinha and Reijnders (2001). 
environmental burden. The latter (Reijnders, I998) was expressed in terms of quantitative reduction of yearly non-product output (e.g. waste, emissions) and resource input (e.g. water, energy) beyond compliance per unit of output.

The strategic objectives and associated performance references may be linked to specific performance evaluation formats. The performance evaluation format was further developed on the basis of an empirical study (Dias-Sardinha et al., 2002) concerned with 35 mainly medium sized organizations operating in Portugal (industries and environmental services).

It was found that the suggested broad strategic objectives and associated performance references were considered useful with the exception of the eco-ethics category. Categories found to be useful by those organizations were current (compliance, pollution prevention) and intended (eco-efficiency, sustainability) strategic objectives and performance status. It was also found that some of these organizations combine two or more of the proposed broad strategic objectives and that also some social issues were addressed. This is in line with Mauser's (200I, p. 29) observation that 'the idea that more than one ideal strategy can lead to an optimal environmental performance may be much closer to reality'. The link between the strategic objective(s) and performance references on one hand and measurements and performance achievements on the other hand was fragmentary for these organizations. Therefore, to improve operationalization of performance evaluation, while focussing on the links between strategic objectives and measurements and expected achievements, a thematic balanced scorecard format (modified from BSI et al., 200I) was proposed to be applied by organizations that strive for sustainability. It covers four main dimensions of or perspectives on and environmental and social aspects of company performance and the financial aspects thereof. These cover a broader range of characteristics than the core performance references outlined by Dias-Sardinha and Reijnders (200I).

In this paper, we further investigate the link between the broad strategic objectives and the format of performance evaluation by using a thematic balanced scorecard format for performance description of I3 large companies operating in Portugal.

Regarding the companies studied we will deal with the following research questions.

(i) Do companies' performance findings fit the categorization made in our previous paper (DiasSardinha and Reijnders, 200I)?

(ii) Is there in the companies a correlation between social and environmental performance?

(iii) What are the driving forces stated to influence environmental initiatives of the companies studied and are these different for different performance categories?

(iv) Is the thematic balanced scorecard format useful as a tool to find strengths and weaknesses of the links between variables of performance evaluation of the companies, i.e. broad strategic objectives on one hand and measurements, initiatives and achievements on the other?

The further structure of the paper is as follows. First, the nature and usefulness of a thematic balanced scorecard are briefly explained and the thematic balanced scorecard format to be used in the performance analysis of the $\mathrm{i} 3$ large companies operating in Portugal is discussed. Thereafter, data collection is outlined and the actual description of company performance using the balanced scorecard format is presented. Next, the paper deals with the identification of driving forces stated to influence environmental management. The paper ends with conclusions and discussion.

\section{The Balanced Scorecard's Context}

Kaplan and Norton (I992a, I992b, I996) first advocated the need for a balanced scorecard (BSC) with financial and non-financial indicators helping managers to evaluate the success of their company. It is 
a management tool that allows evaluation of company performance in view of its strategic objectives. The balanced scorecard that Kaplan and Norton (I992a) proposed highlights four perspectives to look at business: financial, customers, internal processes, and learning and growth.

Environmental and sustainability aspects are strategic for a company as far as they might for instance influence companies' image, profitability, competitiveness, markets and products, which affect economic survival (Kolk, 2000).

Using a balanced scorecard format for assessing the environmental and social performance of companies has been advocated (Johnson, I998; Bennett and James, I999; Epstein and Wisner, 200I; BSI et al., 200I; Bieker and Gminder, 200I; Bieker and Waxenberger, 2002; Figge et al., 2002; Gminder and Bieker, 2002; Hockerts and O’Rourke, 2002).

Such a balanced scorecard may extend an existing balanced scorecard made along the lines proposed by Kaplan and Norton (I992a) or exclusively focus on environmental and social matters including the associated financial aspects. In the latter case the balanced scorecard may be called thematic. A balanced scorecard dealing only with environmental and social issues and financial aspects thereof is useful to highlight priorities and to ensure that important areas are not neglected, as has been pointed out by Bennett and James (I999).

In this research, we have chosen a thematic balanced scorecard format that uses four perspectives, of which the first two are major modifications of the first two used by Kaplan and Norton (I992a). This format is an adaptation of the one proposed by BSI et al. (200I), in which the first perspective concerns the broad environmental strategic objective(s) and social activities and the financial aspects thereof, the 'triple bottom line' in view of value creation. Thus, in this paper, the term triple bottom line will refer to the environmental and social aspects of performance and the financial aspects thereof. This is in line with Cramer (2002, p. 99), who states that 'sustainable business firms need to focus on creating value not only in financial terms but also in ecological and social terms'. The second perspective focuses on stakeholders, the third on processes and the fourth on learning. The indicator categories included in the thematic balanced scorecard such as governance, synergy, compliance and labour practices are roughly the same as those proposed by the Global Reporting Initiative (GRI, 2002), facilitating disclosure in case of sustainability performance reporting.

\section{The Thematic Balanced Scorecard Format Used for Assessment}

In this study, for each of the I3 large companies a description was made of their environmental and social performance and the financial aspects thereof, under each of the four perspectives of the thematic balanced scorecard format outlined above. It was based on specific objectives, initiatives, measurements and achievements ('variables') mentioned by interviewees and/or disclosed by the company. We gave particular attention to the question of whether companies actually met performance references defined in our framework (see Table I) and the previously published thematic balanced scorecard reference format (Dias-Sardinha et al., 2002). The links between the variables mentioned were analysed as communication between organizational levels was also analysed. The four perspectives were defined as follows.

The first perspective (triple bottom line value creation) shows the findings pertinent to the question 'which are the key environmental and social aspects and the financial consequences thereof that the company attends to and are contributing to value creation considering its main environmental/social strategic objective(s)?'. It includes specific objectives, measurements, initiatives, achievements and categories (here defined as indicator categories) relating to governance, compliance, social and environmental issues, the financial aspects thereof and sector issues. 
The second perspective (stakeholders) describes findings pertinent to the question 'what environmental and social aspects does the company attend to and measure to suit internal and external stakeholders and its main environmental/social strategic objective(s)?'. It refers to indicator categories such as business ethics, labour practices and relations with wider society, as reflected in, e.g., ethical codes/ policies, worker satisfaction, communication/reporting, relations with non-governmental companies and philanthropy.

The third perspective (processes) answers the question 'which internal and external processes does the company have and measure regarding environmental and social issues and the financial aspects thereof to achieve its main environmental/social strategic objective(s)?'. This refers to indicator categories related to management structure and systems, use of management tools and technology and products/services and transport. Examples are information systems, environmental and health and safety management plans, environmental programmes and performance evaluation techniques.

The fourth perspective (learning) answers the question 'what learning and innovation skills does the company attend to and measure relevant to the environmental and social strategy and the financial aspects thereof?' This includes indicator categories as such synergy between parts of the company and other companies, training and research and development.

\section{Data Collection}

In our previous paper (Dias-Sardinha et al., 2002), it was found that relatively large Portuguese companies tend to have a more systematic process of performance evaluation than smaller ones and seemed more ambitious as to environmental and social activities. Therefore, in the summer of $200 \mathrm{I}$ we carried out semi-structured interviews of representatives of $\mathrm{I} 3$ large companies ( $>400$ employees) operating in Portugal (Table 2).

The interviews inquired after drivers and matters that were relevant to describe the environmental and social performance and financial implications thereof in the intended format. Ten of the $13 \mathrm{com}$ panies originated in Portugal. The other three are Portuguese subsidiaries of parent companies in another country. The companies that originated in Portugal are in the process of internationalization and expansion and were at the time of interview private. Some of them were traded on the stock exchange. The sales of these Portuguese companies in 200 I vary between 50 and $6 \times 10^{3}$ million euros. The companies with a parent company in another country achieved in $200 \mathrm{I}$ sales of over $\mathrm{I}_{3} \times \mathrm{IO}^{3}$ million euros. The respondents were mostly company officials responsible for environmental matters. Six interviews were with representatives of the parent companies and the others with representatives of business units or sites. Regarding the largest Portuguese company, three interviews were conducted with representatives of three business units. In addition, internally and publicly available information such as annual reports, web information and policy statements were further analysed in the period up to September 2002. Comments from companies given until February 2003 were integrated in the text.

\section{Key Findings on the Current Performance of the Companies}

The specific objectives, measurements, initiatives and main outcomes of these companies mentioned by interviewees or/and disclosed were described using the thematic balanced scorecard format as previously indicated. The companies could be categorized in the first three performance categories of our performance (evaluation) framework (see Table I): compliance with the law, pollution prevention and 
1. Corticeira Amorim Industria, S.A.

2. Atlantis, Cristais de Alcobaca, S.A.

3. Autoeuropa, Automóveis, L.da

4. Celbi

5. Cimpor, S.A.

6. EDP Electricidade de Portugal (production and distribution)

7. Lever

8. Lusotur

9. Pegop Energia Eléctrica, S.A.

10. Portucel-Empresa Produtora de Pasta e Papel, SA

11. Portugal Telecom

12. Secil

13. Sonae SGPS

Sonae Imobiliaria

Sonae Industria

Sonae Turismo
- Cork producer that belongs to Amorim Investimentos e Participações, SGPS, S.A. The latter has five main business areas: cork products, real estate, tourism, textiles and insurance.

- Glass/crystal producer that recently merged with Vista Alegre, which produces porcelain. In Portugal Atlantis has three sites: Atlantis, Crisal and Ivima.

- Car producer that belongs to Volkswagen: a worldwide automotive producer.

- Belongs to StoraEnso, a multinational producer of pulp and paper.

- Cimpor has three cement factories in Portugal and also has business units/sites in Africa (Egypt, Mozambique, Morocco, Tunisia), Spain and Brazil.

- Belongs to EDP parent company that has five business areas: electricity, support services, international, telecommunications and information technologies and multi-services and participations (e.g. water and gas). EDP electricity is also active in Morocco, Cap Verde, Macao, Chile, Guatemala, Brazil and Spain.

- Lever produces detergents and belongs to Unilever, which is represented in Portugal by Iglo, Fima and Lever sites.

- Belongs to Planfipsa (Lusotur e Planbelas). Lusotur manages Vilamoura Resort. Planbelas is developing Belas Clube Campo country club.

- Is an electricity producer joint venture of International Power (UK), Endesa (Spain) and EDF (France).

- Portucel produces pulp and paper and has recently merged with Inapa (paper producer).

- Portugal Telecom (PT) is the telecommunications company in Portugal, which also has facilities in, e.g., Morocco, Botswana and Brazil.

- Secil is owned by a Danish company and small shareholders. It has five main business areas related to building construction material. In Portugal there are three cement factories: Cibra, Outao and Pataias. There are also units in Africa.

- Sonae SGPS has six business areas in real estate, industry, tourism, multimedia, investment and retail.

- Sonae Imobiliaria is the largest developer, investor and manager of shopping and leisure centres in Portugal. It is also active in Spain, Greece, Italy and Brazil.

- Sonae Industria has three business areas: Tafisa (wood based panels), SPDF (other forestry related businesses) in the Iberian Peninsula and SIR (chemicals).

- Sonae Turismo owns resorts and prevides hotel management and services (entertainment and travel).

Table 2. Large organizations interviewed operating in Portugal

eco-efficiency, when considering procedural criteria and the use of management tools. An overview of the performance status of the companies in each category is presented below.

\section{Compliance with Emphasis on Pollution Control}

Two companies (Corticeira Amorim-Industria, S.A.; Atlantis, Cristais de Alcobaca \& Vista Alegre) from the I3 can be categorized as basically aiming at compliance with the law while emphasizing pollution control, though they have some initiatives in pollution prevention. In the social area, there is emphasis 
on compliance with health and safety regulations. There is a positive link between the main strategic objective of compliance with the law and measurement ('monitoring') of compliance, though the statistical representativeness of monitoring may be doubted.

When there are measurements, these are absolute yearly amounts of energy, water, raw material and emissions and indoor air contaminant concentrations at facility level to monitor compliance and to reduce excessive risk and costs. Management performance measurements are not used in performance evaluation in these companies.

Other specific objectives that were mentioned by interviewees such as environmental impact reduction, improvement of organizational structure and systematic efficiency were not found to be subject to evaluation. The main findings are summarized in Table 3.

Under the first perspective and as to environmental and social performance outcomes it can be noted that these two sites are stated to be in compliance. They do not have an environmental company policy and/or a specific reported environmental commitment of management. Thus, there is no specified environmental or social message from the highest level in the company downwards. For the sites of which officials were interviewed there is a recent emergence of site environmental policy.

Regarding the stakeholder's perspective the promotion of a good image is thought to be relevant by interviewees. However, associated initiatives and measurements are limited. At site level, stakeholder specific objectives and measurements are mainly related to workers' exposure to indoor air quality and noise and product safety. These data are not made public but disclosed to regulators. Internal publications aim to increase workers' awareness as to health and safety and environmental matters, the latter in view of the future implementation of an environmental management system.

The process perspective indicates that there is no structure reflecting environmental responsibility at parent company level. The intra-organizational environmental communication seems minimal and is based on individual initiatives. There is a weak link between the specific environmental and social objectives at different organizational levels. However, the Portuguese sites have recently employed technical people who are given environmental responsibility and work is underway on implementation and future certification of environmental management system. There is no systematic setting of priorities and targets at the facilities regarding environmental or social (worker health and safety) activities. Main existent processes are indicated in Table 3.

As to the learning perspective, there is no evidence of substantial synergy between sites although there are initiatives to increase internal environmental awareness. Training of workers in environmental matters and health and safety is being initiated. Process and product research and development initiatives take place in response to customer demand.

\section{Pollution Prevention}

Seven companies (Cimpor; Electricidade de Portugal (EDP); Portucel-Empresa Produtora de Pasta e Papel, S.A.; Planfipsa; Portugal Telecom (PT); Secil; Sonae SGPS) at parent company and/or business unit and/or site level show drive for cost reduction, management attitude, procedural matters and management tools that fits requirements for the pollution prevention performance category (see Table I). The range here is actually considerable and the most advanced ones in this category come close to the eco-efficiency category, when management activities are considered. However, to the extent that environmental reports were available, there were no systematic quantitative data dealing with environmental burden. Thus, it could not be ascertained if the performance reference, reduction of environmental burden by up to $30 \%$, was met.

When quantified targets existed, they dealt mainly with energy and main resources efficiency per site or at parent company level and with compliance. 


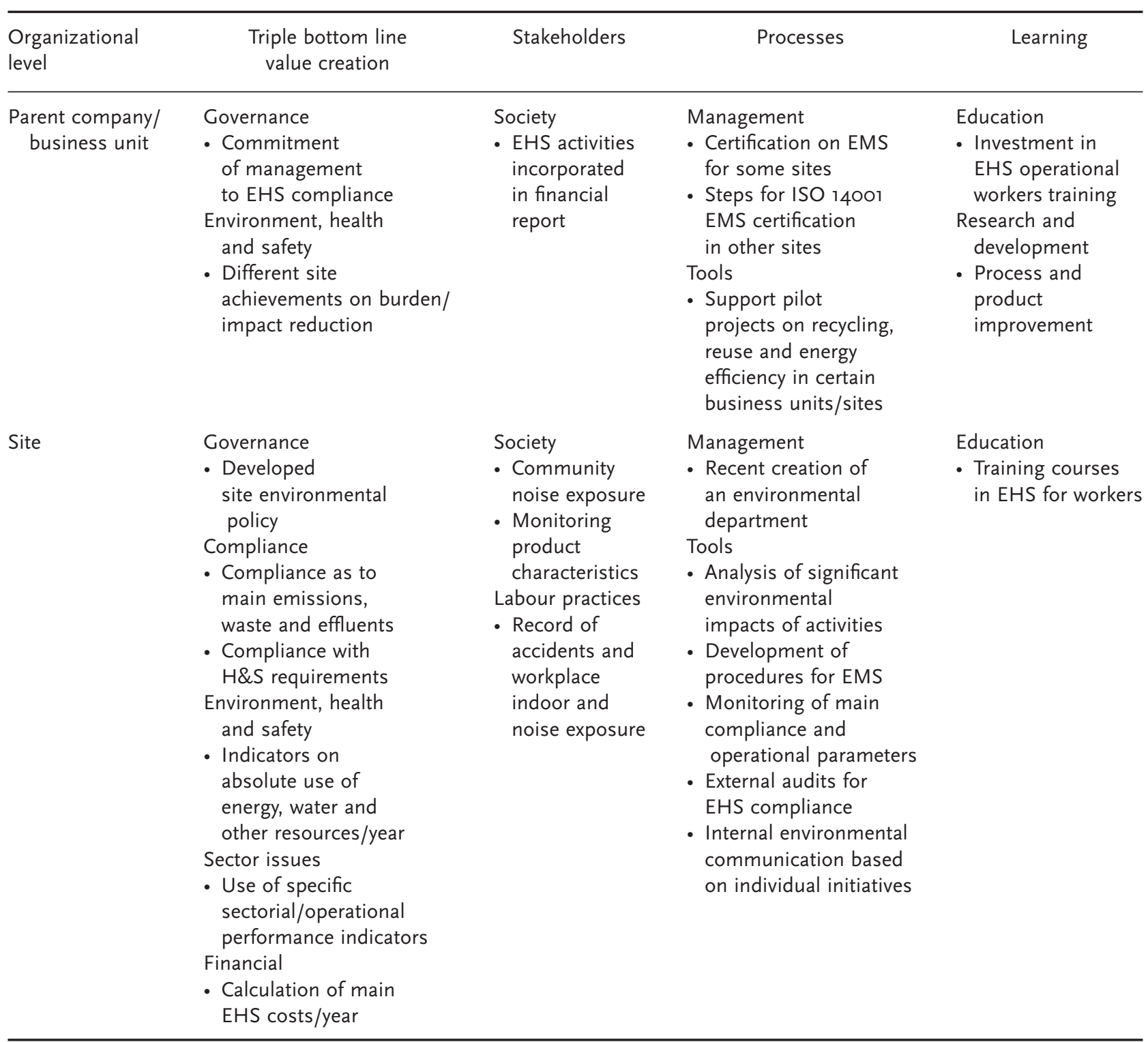

Table 3. Initiatives, measurements and achievements at parent company/business unit and site level mentioned by interviewees and/or publicly disclosed, in a thematic balanced scorecard format for two organizations aiming at compliance with the law, while emphasizing pollution control.

EHS, environment, health and safety; EMS, environmental management system.

Implementation of an environmental management system is required by most of the parent companies. The findings regarding these companies are summarized in Tables 4 and 5 .

Regarding the triple bottom line value creation perspective, the companies involved are characterized by management commitment to integrate environmental issues beyond compliance in the companies' business strategy. Reduction of pollution and the increase of resource productivity through waste minimization, energy efficiency and new product/process opportunities well beyond compliance are aimed at all organizational levels. However, no systematic quantitative targets of environmental burden reduction were found to be pre-defined by the parent company. 


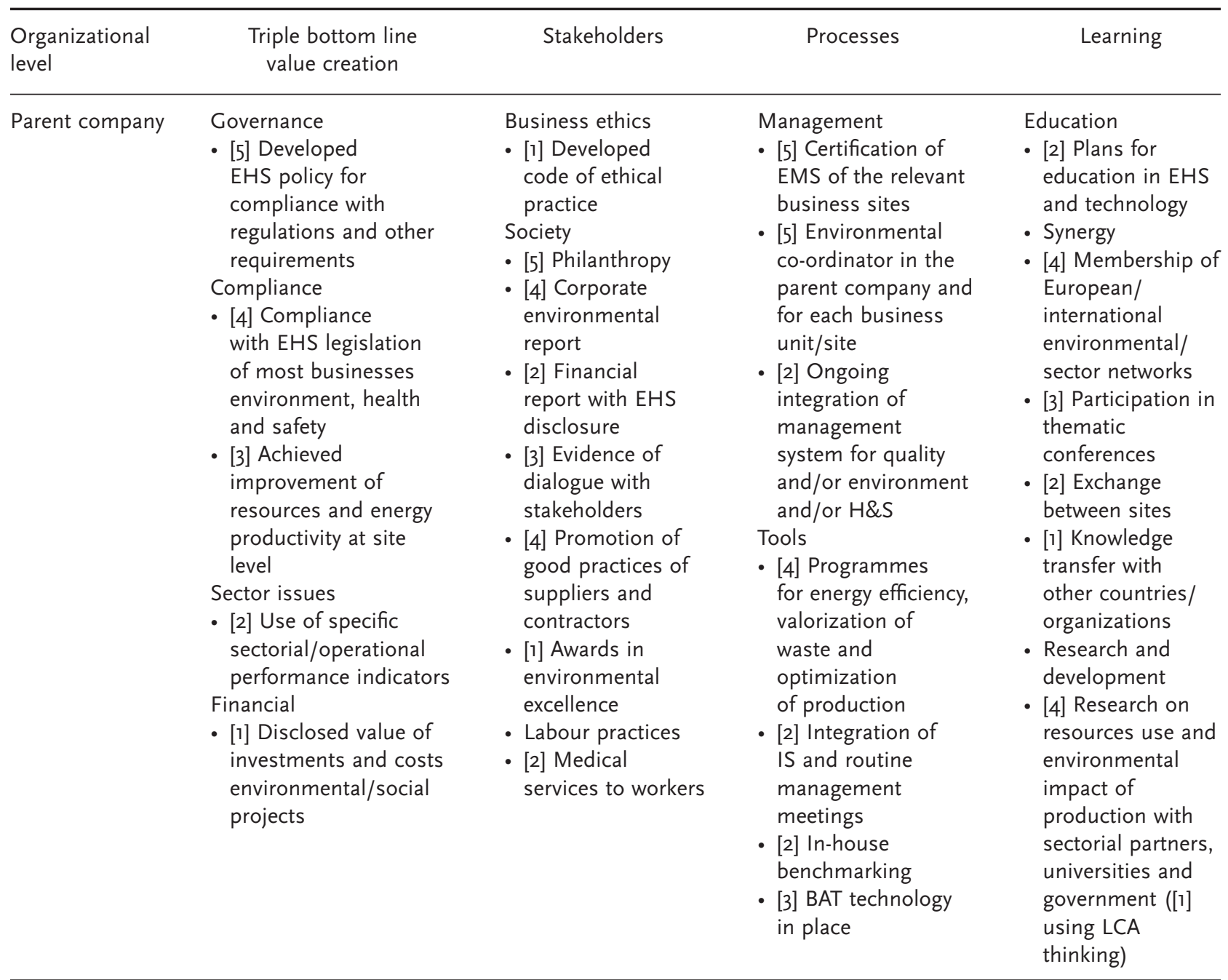

Table 4. Initiatives, measurements and achievements mentioned by interviewees and publicly disclosed at parent company level, in a thematic balanced scorecard format for seven organizations with a pollution prevention performance status of proedural matters and the use of management tools

[\#], number of times mentioned and/or disclosed; EHS, environment, health and safety; LCA, life cycle assessment; EMS, environmental management system; BAT, best available technology; IS, information system; H\&S, health and safety.

Examples of measurements found are described in Box I.

As to the stakeholder perspective, interviewees stated that parent companies have a strong interest in increasing communication with stakeholders about environmental issues such as emissions and environmental management systems and about social matters and the progress therein. Most of these parent companies have issued so far (often two to four) annual parent company environmental reports, though without independent verification. Evolution of regulated pollution parameters in the last 2-4 years and data on energy consumption are disclosed. Public disclosure of percentage of burden reduction achieved beyond compliance and future goals is very limited. There is manifest interest of some parent companies in the future adoption of a sustainability 'corporate' report structure as proposed by the GRI (2002). Sites have a rather systematic monitoring and reporting of accidents to comply with worker health and 


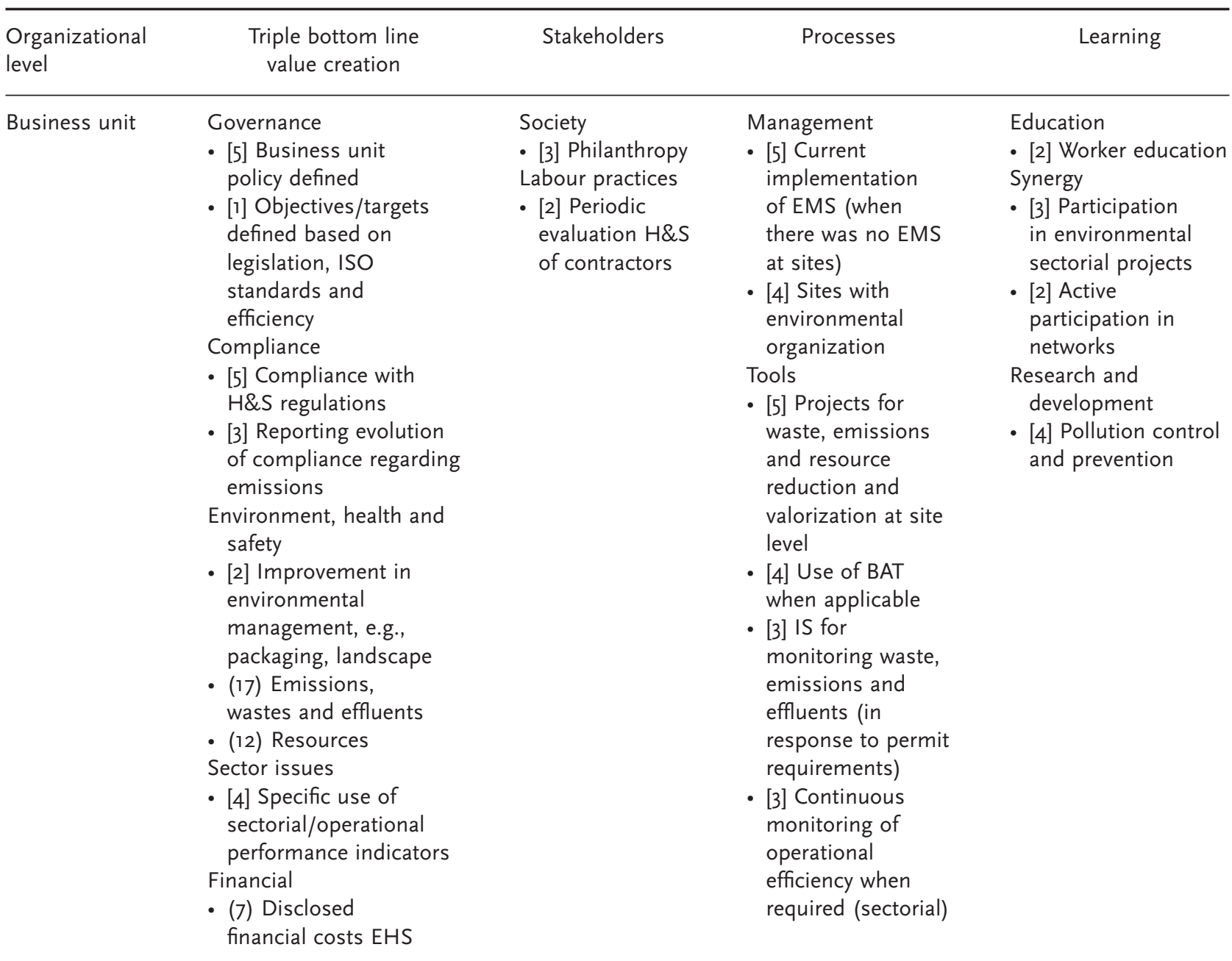

Table 5. Initiatives, measurements and achievements mentioned by interviewees or publicly reported at business unit level, in a balanced scorecard format for seven organizations with a pollution prevention performance status

[\#], number of times mentioned and/or disclosed; (\#), number of indicators mentioned and/or disclosed; EHS, environment, health and safety; EMS, environmental management system; BAT, best available technology; IS, information system.

[2] Total number of cases of non-compliance with; [1] \% of conformity to;

[4] total effluents (e.g., SST, CBO kg/t product/year);

[3] total amount of waste produced; [3] total amount of waste for valorization; [1] total amount of waste recycled, separated and reused; [1] total amount of hazardous waste; [2] total emissions/year;

[1] reduction in total amount of $\mathrm{CO}_{2}$ emitted; [1] emissions year/unit of product;

[1] $\mathrm{CO}_{2}$ emitted/unit product;

[2] total water consumption; [3] total energy consumption and reduction thereof;

[2] total materials used per type; [4] energy/unit product; [1] $\mathrm{m}^{3}$ product/energy used; [1] $\mathrm{m}^{3}$ sold/energy used; [1] unit product/G) consumed; [2] productivity of resources;

[2] total investment in control equipment; [1] green investment/total investment;

[1] health and safety costs; [1] money invested in workers education

$[x]$ number of indicators mentioned by interviewees and/or disclosed.

Box 1. Indicators by companies in the pollution prevention category not shown in Tables 4 and 5 . 
safety legislation. Suppliers' performance is a matter of concern. There is an ambition to improve management of human resources and worker satisfaction. Social issues beyond workers' health and safety, such as philanthropy, activities together with non-governmental organizations and other local community partners are achieved at site level. Business ethics is very rarely referred to.

As to the process perspective, companies involved have allocated environmental structures at the levels of parent company and business units or sites. Central to efforts is the maintenance and/or introduction of certified environmental management systems in all or most of the sites. Application of best available technologies and good practices tend to be objectives, particularly for companies that will be subject to the Council Directive 96/6I/EC Integrated Pollution Prevention and Control (IPPC, 200I) requirements. In the most advanced companies, use of best available technologies and good practices is actual practice. Most of the sites are running environmental projects aimed at improving burden reduction. Objectives and quantitative targets regarding compliance and operational efficiency are established annually at some sites. A simple information system about measurements is in place in such cases. In-house benchmarking is beginning to be important. There is a growing interest in the implementation of standard health and safety management systems, e.g. OHSAS I800I (I999), and the integration of quality systems with environmental management systems and health and safety issues.

Regarding the learning perspective, workers' environmental awareness and training are objectives mostly associated with implementation of an environmental management system and maintenance. Efforts to create systematic intra-organizational synergy through meetings and common projects have been started. Research and development are usually oriented to reduction of product and process related impacts at site level but there is also involvement in sectorial projects. Networking is very relevant and has substantial influence on company activities.

\section{Eco-efficiency}

Four business units/sites (Autoeuropa Automoveis Lda; Celbi; Lever Portugal; Pegop) could be categorized as in the eco-efficiency category. There is uncertainty however as to the extent that the criterion for environmental burden reduction by $30-75 \%$ was met (see Table I). Current reported practice at the sites did not fully meet this criterion. However, when current improvement rates continue, this criterion may be met in the near future.

The four parent companies provide Portuguese sites with clear annual measurable objectives and targets regarding burden reduction and management initiatives regarding environmental and some social issues. Therefore, performance evaluation is systematic and there is continual incremental improvement as required for this category. Use of most eco-efficient practices and technologies and use of life cycle thinking is practice at site and parent company levels respectively.

Environmental and social reports of Storaenso (of which Celbi is a site), Unilever (Lever site) and Volkswagen (Autoeuropa site) show that these parent companies are evolving with a view to sustainability. However, the full analysis of information disclosed by parent companies was assumed to be out of our scope as the parent company was based outside Portugal. We will refer to reported characteristics of the parent company when it is relevant for the understanding of performance at the business units/sites studied. Findings are summarily presented in Table 6.

Regarding the value creation perspective at business unit/site level the targets refer mainly to operational efficiency, zero complaints, minimization of risks and continuous improvement reflected in environmental and social impact reduction. Annual targets are mostly achieved. Contribution to global effects such as climate change may be reported at parent company level. Main operational costs and investments concerning environmental activities are disclosed. The percentage of sites of the parent company with a certified environmental management system is high (e.g., Storaenso has $80 \%$ of its 


\begin{tabular}{|c|c|c|c|c|}
\hline $\begin{array}{l}\text { Organizational } \\
\text { level }\end{array}$ & $\begin{array}{l}\text { Triple bottom } \\
\text { line value creation }\end{array}$ & Stakeholders & Processes & Learning \\
\hline
\end{tabular}

Table 6. Initiatives, measurements and achievements mentioned by interviewees and/or publicly disclosed at business units/site level in a balanced scorecard format for four organizations with an eco-efficiency status based on procedural matters and the use of management tools

[\#], number of times mentioned and/or reported; (\#), number of indicators mentioned and/or disclosed; EHS, environmental, health and safety; EMS, environmental management system; BAT, best available technology; IS, information system; H\&S, health and safety. 
[4] Meeting annual predefined corporate goals and achieving continuous improvement (e.g., \% projects that achieved target; $\%$ achieved objectives; maintaining EMAS and/or EMS certification);

[3] total use of energy and water; [2] \% water reduction/t or unit;

[2] input materials/t product; [1] \% renewable energy consumption;

[3] \% reduction of emission or effluents; [1] total amount of waste/unit; [1] total amount of waste for external valorization; [1] $\mathrm{CO}_{2}$ emissions/t product, unit;

[4] number of accidents; total air contaminant concentration;

[2] $\mathrm{km} /$ unit of production distributed; total amount packaging/unit;

[2] \% reduction of environmental costs; [1] money spent in projects for local community; [2] investments in environment, health and safety

[x] number of indicators mentioned by interviewees and/or disclosed.

Box 2. Indicators by companies in the eco-efficiency category not shown in Table 6.

sites certified) and registration of European sites in the European Audit Management Scheme is common. The parent company may be listed in the DJSGI (I999) (e.g. Storaenso and Volkswagen). Examples of the measurements found are described in Box 2.

Regarding the stakeholder's perspective, the objective of transparency to and dialogue with stakeholders at parent company and site level is clear.

At parent company level, there is a coherent disclosure regarding environmental and social issues and financial aspects thereof, often for the last 5-IO years. 'Corporate' social responsibility shapes parent company reports, which often deal with product development. External site reporting is required for registered sites in the Eco-Management and Audit Scheme (EMAS) (I993). At site level, annual disclosure includes achievements regarding targets that were mostly proposed by the parent company regarding continuous environmental and sometimes social improvement. Guarantee of workers' health and safety, their satisfaction and motivation are site goals. Therefore, health and safety systems are brought up to recognized standards such as OHSAS i800I (I999) and up to date human resources policies are established. One company has instituted workers' profit sharing that is also linked to environmental performance. Measurements and achievements regarding wider societal issues at site level are limited but there is philanthropy towards local communities.

As to the process perspective environmental management systems are being integrated with health and safety and quality systems. One of the companies issued a yearly site business balanced scorecard that is disclosed to workers. It includes environmental and social matters that in $200 \mathrm{I}$ referred to resource productivity, emission reduction, health and safety and environmental management system compliance and maintenance. Human resource improvement, worker education and societal relations at sites were also referred to in the balanced scorecard. At site level, meeting targets issued by the parent company and internal benchmarking are found to be very important. Benchmarking with respect to other companies is performed at parent company level. Controls pertinent to meeting targets and internal audits are systematic. Technology and management practices are regularly updated in line with the continuous improvement requirements based on internal audits and complaints. Requirements regarding production or product improvement are introduced at production sites.

Regarding the learning perspective, synergy between the parent company and sites seems to be present. Networks with sectorial and technical partners are established. Product oriented research and development, e.g. in product life cycle analysis, are mainly done at parent company level with the aim of product improvement. At site level, the research and development focus is on process improvement necessary for product improvement. Worker education is broader than environmental and health and safety matters and seems to be regularly updated. 


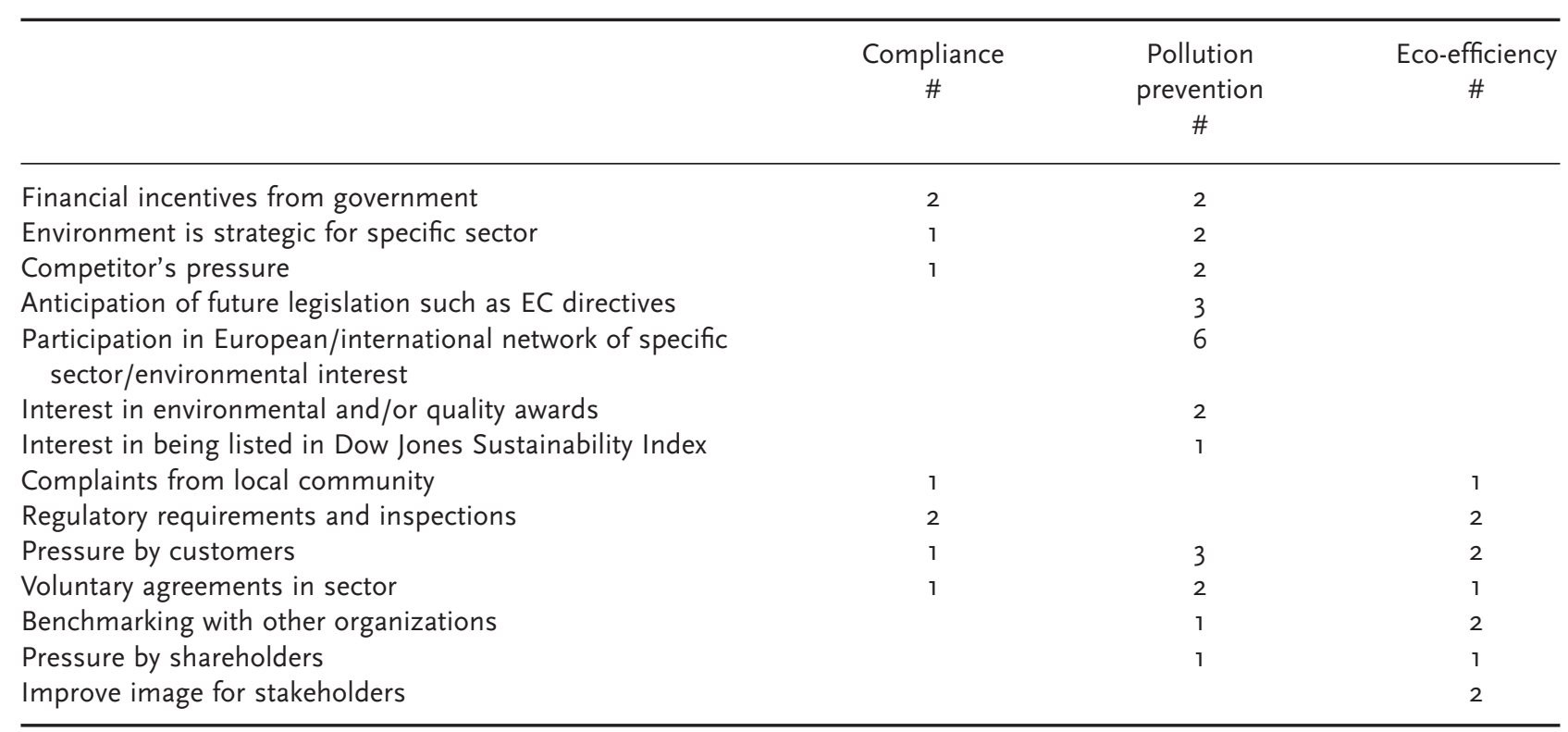

Table 7. External driving forces for implementation of environmental initiatives in the studied organizations \# Number of times mentioned by interviewees.

\section{Driving Forces for Environmental Management}

Analysis of driving forces for environmental management provides clues as to the relations of companies with their stakeholders and the reasons for adopting objectives and practices. Tables 7 and 8 show the external and internal driving forces that were mentioned by interviewees ordered by the performance category (compliance, pollution prevention and eco-efficiency) of the studied companies.

Participation in international trade and environment networks and pressure from government and customers are the external drivers that were mentioned most frequently. Companies that we categorize to be in the pollution prevention category are anticipating expected legislation, open to networking and interested in awards.

Internally, leadership culture and objectives from management were said to be the main drivers.

There seems to be a difference in types of internal driver for the three categories of companies found in this study. The companies striving for compliance appear to be mainly driven by the perceived need to reduce costs and government pressure. Companies in the pollution prevention category seem to be essentially driven by the perceived need to use environmental performance responding to the increasing competitiveness with other companies and to help business strategy. Interviewees stated that openness of data on emissions, environmental management and social issues were found to be important 'to make a positive impression' on stakeholders such as regulators and bankers. This seems even more relevant for companies in the process of growing internationalization.

As to sites categorized as eco-efficient, interviewees mentioned particularly requirements by the parent company and improved competitiveness with sites belonging to the same company. Interviewees considered systematic and open communication between workers and management as being relevant for success. They stated that transparency and dialogue with stakeholders are important to brand and parent company reputation and that the recent corporate social responsibility and sustainability concepts are relevant for action. 


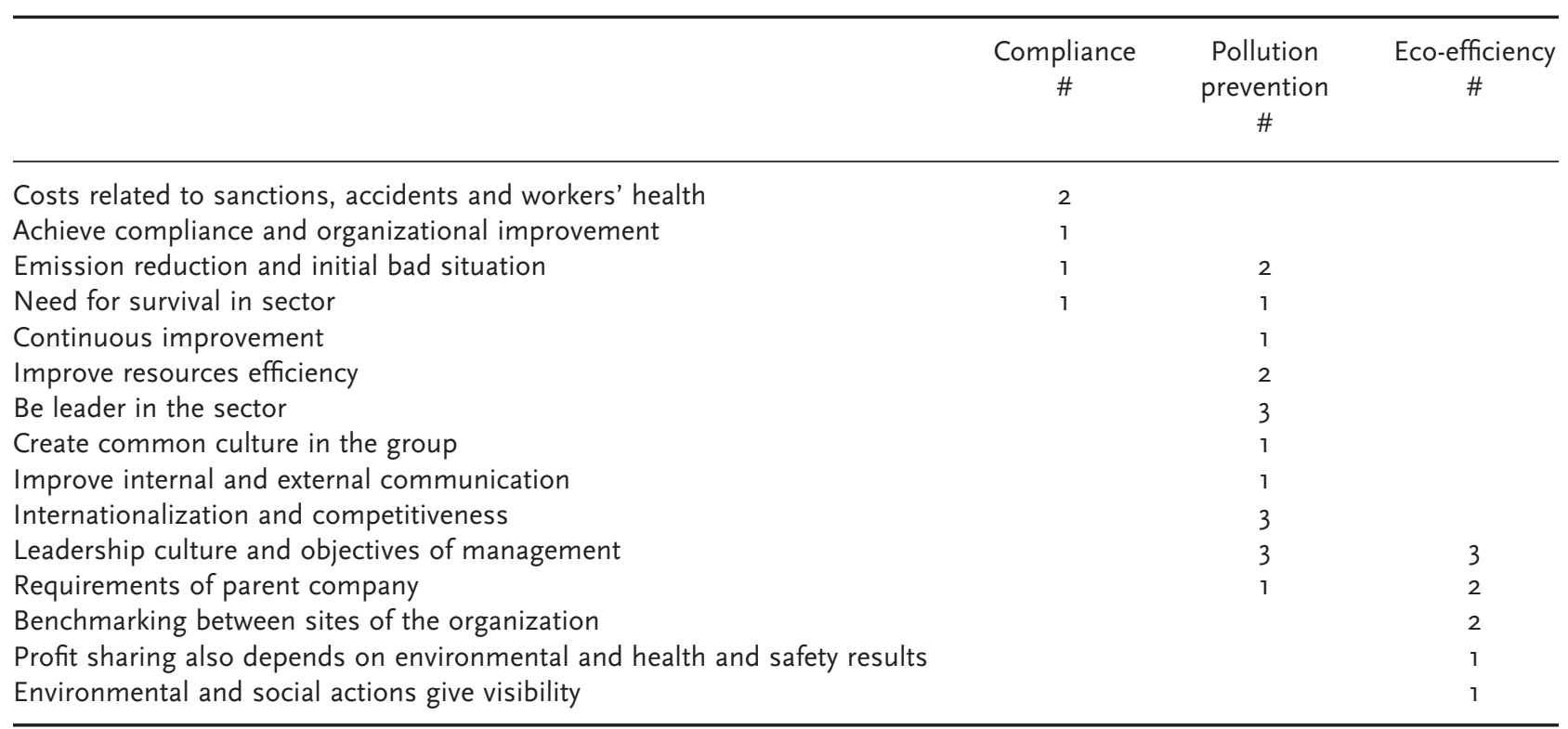

Table 8. Internal driving forces for implementation of environmental initiatives in the studied organizations \# Number of times mentioned by interviewees.

\section{Conclusions and Discussion}

In general, the evaluation of company performance in this paper is based on alleged behaviour. No independent check on actual performance was made. With this proviso the following conclusions can be drawn.

Regarding research question (i) outlined in the introduction, it was found that the performance categories of eco-innovation, eco-ethics and sustainability described in our performance framework (DiasSardinha and Reijnders, 200I) were not found in the sample of companies studied.

Based on procedural matters and the use of management tools companies could be categorized as focussing on compliance, pollution prevention and eco-efficiency. However, it was unclear whether the companies categorized as belonging to the pollution prevention and eco-efficiency categories meet the suggested requirements regarding reduction of environmental burden. Data in Tables 2-6 and Boxes I and 2 also show that type and number of indicators differ by performance category.

As to research question (ii) it was found that improvement of performance in the environmental field is, in our sample, in parallel with improved performance in the social field. However, social aims seem less ambitious than environmental ones and seem more developed at site level. That there is a parallel between environmental and social activities suggests that widening the essentially environmental performance categorization proposed by Dias-Sardinha and Reijnders (200I) to a multi-level sustainability performance categorization may be feasible for the companies studied here. This is in line with recent work of van Marrewijk and Werre (2002), which suggests a multiple level corporate sustainability framework.

Regarding research question (iii), we note that in our sample driving forces for environmental and social action differ partially by category of performance. The two companies striving for compliance are mainly driven by the need to reduce costs and by government pressure. The companies in the pollution prevention category seem to be driven internally by the perceived need to use environmental perfor- 
mance to increase competitiveness and help business strategy. Networking is a relevant external driver. The sites in the eco-efficiency category seem driven by requirements from the parent company and considerations regarding competitiveness inside the company.

In the performance evaluation of the companies studied we found a parallel evolution of specific activities mentioned by interviewees. The latter are first management systems (e.g. environmental management system, total quality management, integrated environmental health and safety systems) and second the use of environmental tools/techniques (e.g. impact assessment, performance measurement analysis, reporting, benchmarking, risk assessment, auditing). The finding of this parallel evolution complements findings of Roy et al. (200I), who found a positive correlation between environmental commitment and variables in stakeholders' management, manufacturing practices and competitive performance. However, there appears to be a two-speed development of on one hand implementation of management systems and tools and on the other hand the use of targets and the measurement of achievements. The use of the latter is lagging behind. This is especially so for the measurement of environmental burden and social impact. This is in line with findings of Jung et al. (200I) that suggest a gap between what companies have as ambition and disclose as their actual achievements.

The later suggests the usefulness of the thematic balanced scorecard in finding the weaknesses and strengths of the links between the variables of the performance evaluation of the companies. This answers research question (iv). The use of the thematic balanced scorecard format for assessment also allowed us to present all predefined determinants for performance evaluation, checking first the value of the performance references proposed before (see Table I) and second the format and content of the thematic balanced scorecard proposed by Dias-Sardinha et al. (2002). The format of the balanced scorecard allows verification of the existence of links between the broad strategic objectives and performance references with specific objectives, measurements, initiatives and achievements.

The use of the thematic balanced scorecard format as a tool for analysis did show that different matters can be important at different intra-organizational levels in the company. First, this is evidenced by the differences in what is important for performance evaluation between parent company and site. For instance, product life cycle analysis tends to be done at the parent company, with sites specializing in parts of the life cycle (clean technology). In view of the data assembled here sectorial and driver-specific considerations need to be taken into account when developing performance evaluation in the parent company. Companies involved in more than one sector have developed activities regarding environmental and social issues driven by the most important business unit and/or because environmental activities can be used for differentiation (e.g. tourism).

\section{Acknowledgements}

Idalina Dias-Sardinha's work is funded by FCT, programme PRAXIS XXI, Portugal. We would like to acknowledge the essential and outstanding cooperation of our respondents, the useful help and comments on the paper from Paula Antunes and the work of Patricia Cardoso and Catarina Rebelo regarding data collection. We would also like to acknowledge the reviewers for their thoughtful comments.

\section{References}

Aragon-Correa JA. I998. Strategic proactivity and firm approach to the natural environment. Academy of Management Journal 4I $(5): 556-567$.

Atkinson G. 2000. Measuring corporate sustainability. Journal of Environmental Planning and Management 43(2): 235-252.

Azapagic A. 2004. Developing a framework for sustainable development indicators for the mining and minerals industry. Journal of Cleaner Production I2(6): 639-662. 
Azzone G, Manzini R. I994. Measuring strategic environmental performance. Business Strategy and the Environment 3(I): I-I4. Azzone G, Manzini R, Noci G, Welford R, Young W. I996. Defining environmental performance indicators: an integrated framework. Business Strategy and the Environment 5(2): 69-80.

Bartolomeo M. I995. Environmental Performance Indicators in Industry. Fondazione ENI Enrico Mattei: Milan.

Bennett M, James P. I999. ISO I403I and the future of environmental performance evaluation. In Sustainable Measures: Evaluation and Reporting of Environmental and Social Performance, Bennett M, James P, Klinkers L (eds). Greenleaf: Sheffield; 76-97.

Bieker T, Gminder C-U. 200I. Towards a sustainability balanced scorecard. Paper presented at Oikos PhD Summer Academy 200I Environmental Management and Policy and Related Aspects of Sustainability.

Bieker T, Waxenberger B. 2002. Sustainability balanced scorecard and business ethics. Paper presented at the Greening of Industry Network Conference 2002, Göteborg, Sweden.

BMU, UBA. I997. Guide to Corporate Environmental Indicators. German Federal Ministry of Environment and German Federal Environment Agency: Bonn.

British Standards Institute (BSI), AccountAbility, Forum for the Future. 200I. The SIGMA Project: Sustainability in Practice. http://www.projectsigma.com/ [4 March 2002].

Callens I, Wolters L. I998. Factors of unsustainability: identification, links and hierarchy. Business Strategy and the Environment 7: 32-42.

Cramer J. 2002. From financial to sustainable profit. Corporate Social Responsibility and Environmental Management 9: 99-Io6.

de Bakker FGA. 200I. Product-Oriented Environmental Management. Twente University Press.

Dias-Sardinha I, Reijnders L. 200I. Environmental performance evaluation and sustainability performance evaluation of companies: an evolutionary framework. Eco-Management and Auditing 8(2): 7I-79.

Dias-Sardinha I, Reijnders L, Antunes P. 2002. From environmental performance evaluation to eco-efficiency and sustainability balanced scorecards. A study of companies operating in Portugal. Environmental Quality Management Winter: 5I-64.

Dow Jones Sustainability Group Index (DJSGI). I999. http://indexes.dowjones.com [I2 November I999].

Eagan P, Joeres E. I997. Development of a facility based environmental performance indicators related to sustainable development. Journal of Cleaner Production 5(4): 269-278.

Eco Management and Audit Scheme (EMAS). I993. EC No. I836/93.

Epstein, MJ, Wisner P. 200I. Using a balanced scorecard to implement sustainability. Environmental Quality Management Winter: I-IO.

Figge F, Hahn T, Schaltegger S, Wagner M. 2002. The sustainability balanced scorecard - linking sustainability management to business strategy. Business Strategy and the Environment II: 269-284.

Ghobadian A, Viney H, Liu J, James P. I998. Extending linear approaches to mapping corporate environmental behaviour. Business Strategy and the Environment 7: 13-23.

Gminder C-U, Bieker T. 2002. Managing corporate social responsibility by using the 'sustainability-balanced scorecard'. Paper presented at the Greening of Industry Network Conference 2002, Göteborg, Sweden.

Global Reporting Initiative (GRI). 2002. Sustainability Reporting Guidelines. GRI: Amsterdam, The Netherlands.

Hass JL. I996. Environmental (green) management typologies: an evaluation, operationalization and empirical development. Business Strategy and the Environment 5(I): 59-68.

Hockerts K, O'Rourke A. 2002. The balanced scorecard - a tool to manage social sustainability. Paper presented at the Greening of Industry Network Conference 2002, Göteborg, Sweden.

Hunt CB, Auster ER. I990. Pro-active environmental management: avoiding the toxic trap. Sloan Management Review Winter: $7-\mathrm{I} 8$.

Integrated Pollution Prevention and Control (IPPC). 200I. Directive 96/6I/EC.

International Organization for Standardization (ISO). I999. ISO 14031: Environmental Management - Environmental Performance Evaluation - Guidelines. ISO: Geneva.

Johnson DS. I998. Identification and selection of environmental performance indicators: application of the balanced scorecard approach. Corporate Environmental Strategy 5(4): 34-4I.

Jung EJ, Kim JS, Rhee SK. 200I. The measurement of corporate environmental performance and its application to the analysis of efficiency in oil industry. The Journal of Cleaner Production 9: 55I-563.

Kaplan RS, Norton DP. I992a. The balanced scorecard: measures that drive performance. Harvard Business Review January/ February: 7I-79.

Kaplan RS, Norton DP. I992b. Putting the balanced scorecard to work. Harvard Business Review September/October: I34I42.

Kaplan RS, Norton DP. I996. The Balanced Scorecard: Translating Strategy Into Action. Harvard Business School Press: Boston, MA. 
Kolk A. 2000. The Economics of Environmental Management. University of Amsterdam Faculty of Economics (WIMM): Amsterdam.

Lehni M. I999. Eco-Efficiency Indicators: a Tool for Better Decision-Making - Executive Brief. World Business Council for Sustainable Development: Geneva. http://www.wbcsd.ch [I5 June 2000].

Mauser A. 200I. The Greening of Business Environmental Management and Performance Evaluation: an Empirical Study in the Dutch Dairy Industry. Eburon: Delft.

Occupational Health and Safety Management System (OHSAS I80oI) Specifications. http://emea.bsi-global.com/OHS/ index.xalter [Accessed 3I August 2004].

Olsthoorn X, Tyteca D, Wehrmeyer W, Wagner M. 200I. Environmental indicators for business: a review of the literature and standardisation methods. Journal of Cleaner Production 9(5): 453-463.

Reijnders L. I998. The factor $x$ debate: setting targets for eco-efficiency. Journal of Industrial Ecology 2: 13-22.

Roome N. I992. Developing environmental management strategies. Business Strategy and the Environment I: II-24.

Roy M-J, Boiral O, Lagacé D. 200I. Environmental commitment and manufacturing excellence: a comparative study within Canadian industry. Business Strategy and the Environment Io: 257-268.

Skillius A, Wennberg U. I998. Continuity, Credibility and Comparability: Key Challenges for Corporate Environmental Performance Measurement and Communication. IIIEE: Lund.

Thoresen J. I999. Environmental performance evaluation - a tool for industrial improvement. Journal of Cleaner Production 7 : $365-370$.

Upham P. 2000. An assessment of the natural step theory of sustainability. Journal of Cleaner Production 8: 445-454.

van Berkel R. 2000. Sustainable on Environmental Issues and Waste Management in Energy and Mineral Production. Alberta, Canada, 30 May-2 June. Curtin University of Technology: Perth, Australia; I-I7.

van Hemel CG. I998. Eco-Design Empirically Explored. Design for Environment in Dutch Small and Medium Enterprises. Delft University of Technology-Boekland MilieuBoek: Amsterdam.

van Marrewijk M, Werre M. 2002. Multiple levels of corporate sustainability. Meeting of the European Corporate Sustainability Framework September 2002, Rotterdam.

Veleva V, Ellenbecker M. 20ог. Indicators of sustainable production: framework and methodology. Journal of Cleaner Production 9(6): 519-549.

Wehrmeyer W. I995. Measuring Environmental Business Performance: a Comprehensive Guide, Business and the Environment Practitioner Series, Hillary R (ed.). Thornes: Cheltenham, UK.

Young W, Welford R. I999. An environmental performance measurement framework for business. In Sustainable Measures: Evaluation and Reporting of Environmental and Social Performance, Bennett M, James P, Klinkers L (eds). Greenleaf: Sheffield, pp. 98-II6.

\section{Biography}

Idalina Dias-Sardinha (corresponding author) is a Ph.D. candidate and her work is being funded by Fundação para Ciência e Tecnologia (FCT) PRAXIS programme - ref. BD/I829I/98, Portugal. She can be contacted as follows: University of Amsterdam, IVAM, PO Box I8I80, I00 Z ZB Amsterdam, The Netherlands.

Tel.: +3I 20525 59I5

Fax: +3I 205255850

E-mail address: limadias@sapo.pt

Lucas Reijnders is Professor of Environmental Science at the University of Amsterdam (IBED), the Netherlands. He can be contacted as follows: University of Amsterdam, IBED, PO Box I8I80, IO०I ZB Amsterdam, The Netherlands.

Tel.: +31 205256269

Fax: +3I 205255850

E-mail address: 1.reijnders@frw.uva.nl 